\title{
Alberta continues cat-and-mouse game with reform
}

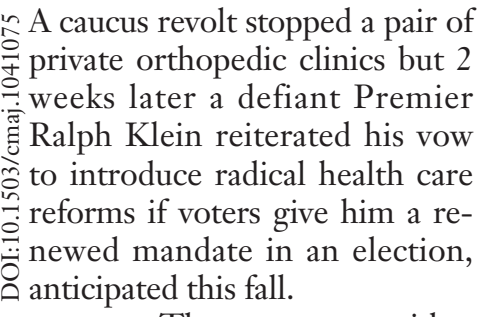

That vow came with a

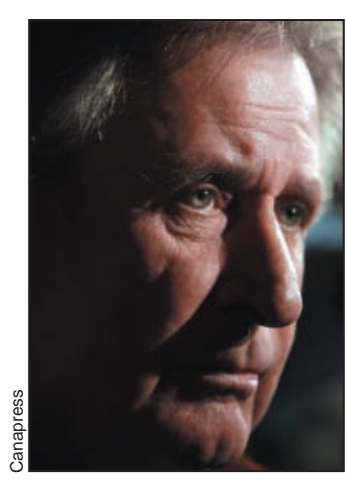
velvet glove: $\$ 700$ million in new money to fund programs, buy equipment, wipe away regional health authority deficits and begin or advance capital projects.

"We are fortunate in Alberta to be able to make this investment so we can take immediate action on Albertans' health priorities," Klein said. "Other challenges remain, and we need to meet them, but we will do so only after we Klein's reform: Deductibles? Privatization? have had a public discussion."

To fuel that discussion, Klein released 2 commissioned reports: one from the Conference
Board of Canada detailing health outcomes from countries with less expensive health systems, the other a government committee report.

The latter, dubbed the Graydon report after chairman Gordon Graydon (http://www .health.gov.ab.ca), suggests ways to raise government revenue including increasing health care premiums by $7 \%$ (up from $13 \%$ now), privatizing long-term care facilities and introducing a health care insurance deductible.

Under the deductible plan, Albertans would pay for their health care to a limit of $1.5 \%$ of their annual income and the province would pay the rest. Some call it a tax on the sick and claim it contravenes the Canada Health Act.

Critics pounced on the announcement saying the Graydon report, Klein's preference for private orthopedic clinics and his $\$ 700$ million health care salve are signs of muddled intentions and failed leadership.

"Albertans have spoken loudly for 10 years. They want a strong, well-managed public system. But the government doesn't like that answer," says Liberal Leader Kevin Taft. He advocates a stable, public system. "It's too bad health care was not more insulated from these political whims."

Harvey Voogd, of Friends of Medicare lobby group, says more privatization leads to less public control over spending. Bulk buying, better fiscal management and more federal dollars would help make health care sustainable, he said.

Doctors and health authorities welcomed the new money but said little about the possibility of user fees and private hospitals.

The Alberta Medical Association won't comment until the proposed reforms are implemented. - Lisa Gregoire, Edmonton

\section{Health Care finance}

\section{Germany's new user fee cuts doctor visits}

Visits to physicians have decreased after the German government introduced a controversial $£ 10$ (about Cdn\$16.50) user fee in January. Patients must pay for their first doctor's appointment each quarter.

During the first quarter of 2004 , there was an average decrease in doctor visits of $10 \%$, according to figures the Association of Statutory Insurance Physicians (KBV) released in late April. General practitioners saw $9 \%$ fewer patients, and consultants $10.5 \%$.

The government introduced the fee in January 2004 as part of health reform package to cut increasing health costs. After running a £2-billion (Cdn\$3.3billion) annual deficit for 3 years, the statutory health insurance system has moved into the black, making it possible to reduce monthly insurance payments.
"The fee is accomplishing its regulatory effect," Health Minister Ulla Schmidt said.

But the physicians' association believes the crucial question is "not just how many people are staying away from the doctor's, but who is staying away," says spokesperson Roland Stahl.

A June survey by the Employees Health Insurer, a public-private agency, indicates $9 \%$ of those insured went to work despite feeling slightly ill. Twenty percent of those who had reported in sick for less than 3 days in 2003 admitted they visited the doctor mainly to get permission to stay home.

"These results clearly suggest that unnecessary doctor visits are being avoided, which argues in favour of the fee," says Rolf Mentzell, the Health Insurer's spokesperson in Hamburg.

The physicians' association ar- gues the fee will work well if it deters those with a compulsion to make multiple doctor visits. "Doctors will have more time for the genuine patients, which is what we and the lawmakers want. But if the fee keeps socially disadvantaged patients away, naturally it would be disastrous," says Stahl.

That's exactly what's happening, says the General Association of Patients, a lobby group. "The fee operates by social selection," says Christian Zimmermann in Marburg. "For those who earn enough, $£ 10$ is nothing ... while those who live in difficult financial circumstances have to think twice."

The initial drop in doctor visits may be partially explained by a last-minute rush to beat the fee at the end of 2003 , says Stahl. - Claudia Orellana, Tubingen, Germany 